Article

\title{
Epoprostenol Delivered via High Flow Nasal Cannula for ICU Subjects with Severe Hypoxemia Comorbid with Pulmonary Hypertension or Right Heart Dysfunction
}

\author{
Jie Li *(D), Lauren J. Harnois, Bethelhem Markos, Keith M. Roberts, Salma Al Homoud, Jing Liu, \\ Sara Mirza and David Vines \\ Department of Cardiopulmonary Sciences, Division of Respiratory Care, Rush University Medical Center, \\ Chicago, IL 60130, USA; Lauren_J_Harnois@rush.edu (L.J.H.); Bethelhem_Markos@rush.edu (B.M.); \\ kmr8106@sbcglobal.net (K.M.R.); salmakamelh@gmail.com (S.A.H.); jane.liu.uru@gmail.com (J.L.); \\ Sara_Mirza@rush.edu (S.M.); David_Vines@rush.edu (D.V.) \\ * Correspondence: Jie_Li@rush.edu; Tel.: +01-312-947-0065
}

Received: 29 April 2019; Accepted: 10 June 2019; Published: 14 June 2019

\begin{abstract}
Inhaled epoprostenol (iEPO) has been utilized to improve oxygenation in mechanically ventilated subjects with severe hypoxemia, but the evidence for iEPO via high-flow nasal cannula (HFNC) is rare. Following approval by the institutional review board, this retrospective cohort study evaluated subjects who received iEPO via HFNC for more than $30 \mathrm{~min}$ to treat severe hypoxemia comorbid with pulmonary hypertension or right heart dysfunction between July 2015 and April 2018. A total of 11 subjects were enrolled in the study of whom 4 were male (36.4\%), age $57.5 \pm 22.1$ years, and APACHE II score at ICU admission was $18.5 \pm 5.7$. Ten subjects had more than three chronic heart or lung comorbidities; seven of them used home oxygen. After inhaling epoprostenol, subjects' $\mathrm{SpO}_{2} / \mathrm{F}_{\mathrm{I}} \mathrm{O}_{2}$ ratio improved from $107.5 \pm 26.3$ to $125.5 \pm 31.6(p=0.026)$ within $30-60 \mathrm{~min}$. Five subjects $(45.5 \%)$ had $\mathrm{SpO}_{2} / \mathrm{F}_{\mathrm{I}} \mathrm{O}_{2}$ improvement $>20 \%$, which was considered as a positive response. Heart rate, blood pressure, and respiratory rate were not significantly different. Seven subjects did not require intubation, and seven subjects were discharged home. This retrospective study demonstrated the feasibility of iEPO via HFNC in improving oxygenation. Careful titration of flow while evaluating subjects' response may help identify responders and avoid delaying other interventions. This study supports the need for a larger prospective randomized control trial to further evaluate the efficacy of iEPO via HFNC in improving outcomes.
\end{abstract}

Keywords: high-flow nasal cannula; epoprostenol; inhalation; hypoxemia

\section{Introduction}

Inhaled epoprostenol (iEPO) is a selective pulmonary vasodilator that has been shown to be equally effective as inhaled nitric oxide (iNO) in reducing pulmonary artery pressure [1-4] and improving oxygenation [5-7], with similar incidence of complications in mechanically ventilated subjects. Compared to systemic use of epoprostenol, iEPO has more specific pulmonary vasodilation effects. The reduction of pulmonary vasculature resistance was more significant while the systemic blood pressure was less affected [1]. Moreover, iEPO is 4.5 to 17 times less expensive than iNO, depending on the institution's contracted price [3,7]. Due to these financial savings, there is a growing trend of substituting iEPO for iNO in mechanically ventilated subjects. However, the evidence for using iEPO in subjects who are extubated or spontaneously breathing is scarce. The only study using iEPO delivered via mask in spontaneously breathing subjects showed no differences between iEPO 
and iNO in regards to acute hemodynamic effects [4]. But However, iEPO delivery via mask is not feasible for long-term use due to its inconvenience and discomfort. Given the expense of using inhaled pulmonary vasodilators for pulmonary hypertension or hypoxemia subjects and the clinical impact of compliance with the prescribed therapy as well as the short half life time of iEPO, there is a need to determine a more feasible manner to deliver iEPO.

An alternative to mask administration of iEPO for spontaneously breathing subjects is high-flow nasal cannula (HFNC), which has been shown to be effective in improving oxygenation and avoiding intubation in randomized controlled trials [8,9]. Consequently, HFNC is more suitable and feasible for long-term use. Aerosol delivery via HFNC may minimize interruptions and improve subject compliance [10]. HFNC has been shown to deliver clinically relevant masses of medicated aerosol in both in vitro [11-14] and in vivo studies [14,15]. Two retrospective studies in pediatric asthmatic and bronchiolitis subjects reported that combined use of vibrating mesh nebulizer (VMN) and heated HFNC to deliver bronchodilators helped avoid intubation [16,17]. Three recent clinical trials demonstrated that using a jet nebulizer [18] or VMN [19,20] to deliver bronchodilator via HFNC for chronic obstructive pulmonary disease (COPD) subjects has similar efficacy as jet nebulizer via mouthpiece. However, no clinical study has been completed to evaluate the efficacy of iEPO via HFNC or the dosage of iEPO needed via HFNC to produce a clinically significant effect.

Over the past three years, iEPO via HFNC has been used for subjects with hypoxemia comorbid with pulmonary hypertension or right heart dysfunction in the adult Intensive Care Units (ICUs) at Rush University Medical Center. This retrospective study was conducted to evaluate the impact of delivering iEPO via HFNC on oxygenation in spontaneously breathing subjects and assess its potential impact on subjects requiring mechanical ventilation.

\section{Materials and Methods}

\subsection{Study Design}

Following approval by the institutional review board (No. 17062302-IRB01, approved on 8/8/2017 and amendment was approved on 11/19/2018) in Rush University Medical Center, a retrospective chart review was conducted in adult ICUs with a total 112 beds in a 644-bed tertiary university hospital. Subjects who were $\geq 18$ years old and received iEPO via HFNC to treat severe hypoxemia were enrolled from a registry database in the respiratory care department. Severe hypoxemia was defined as requiring a fraction of inspired oxygen $\left(\mathrm{F}_{\mathrm{I}} \mathrm{O}_{2}\right)$ via $\mathrm{HFNC}>0.5$ to maintain the blood oxygen saturation $\left(\mathrm{SpO}_{2}\right)$ at 88-93\%. Exclusion criteria were: (1) iEPO was utilized less than $30 \mathrm{~min}$, (2) palliative care.

\section{2. iEPO Use via HFNC}

We started using iEPO in adult intensive care units in July 2015. A protocol was created to initiate iEPO which included step-by-step instructions, and the indications for using iEPO were as follows: (1) acute respiratory distress syndrome (ARDS) with partial pressure of oxygen in arterial blood/ fraction of inspired oxygen $\left(\mathrm{PaO}_{2} / \mathrm{F}_{\mathrm{I}} \mathrm{O}_{2}\right)$ ratio of $\leq 200$, (2) Pulmonary hypertension with mean pulmonary arterial pressure (mPAP) $\geq 30 \mathrm{mmHg}$ or systolic pulmonary arterial pressure (sPAP) $\geq 40 \mathrm{mmHg}$; (3) Right heart failure with central venous pressure (CVP) $\geq 15 \mathrm{mmHg}$ with cardiac index (CI) $<2.2 \mathrm{~L} / \mathrm{min} / \mathrm{m}^{2}$. When iEPO was delivered via HFNC, a vibrating mesh nebulizer (Aerogen ${ }^{\circledR}$ Solo, Aerogen Ltd., Chicago, USA ) was placed upstream (dry side) of a heated humidifier in the Optiflow ${ }^{\mathrm{TM}}$ system (MR 850, Fisher \& Paykel, Auckland, New Zealand) (Figure 1). Flow was initiated at 30 L/min and then titrated up to $50 \mathrm{~L} / \mathrm{min}$ if subjects tolerated it.

Veletri (epoprostenol) (1.5mg) was reconstituted with sterile water, according to the manufacturer's instructions. The solution was drawn into a $60-\mathrm{mL}$ syringe and attached to the VMN reservoir via a segment of tubing. The syringe was connected to the Alaris Syringe Module (Carefusion, San Diego, CA, USA), which was configured to administer continuous nebulization of epoprostenol. The dose of 
iEPO was decided by subjects' ideal body weight starting at $50 \mathrm{ng} / \mathrm{Kg} / \mathrm{min}$ and weaned by $10 \mathrm{ng} / \mathrm{Kg} / \mathrm{min}$. The duration of iEPO was determined based on the subject's clinical response.

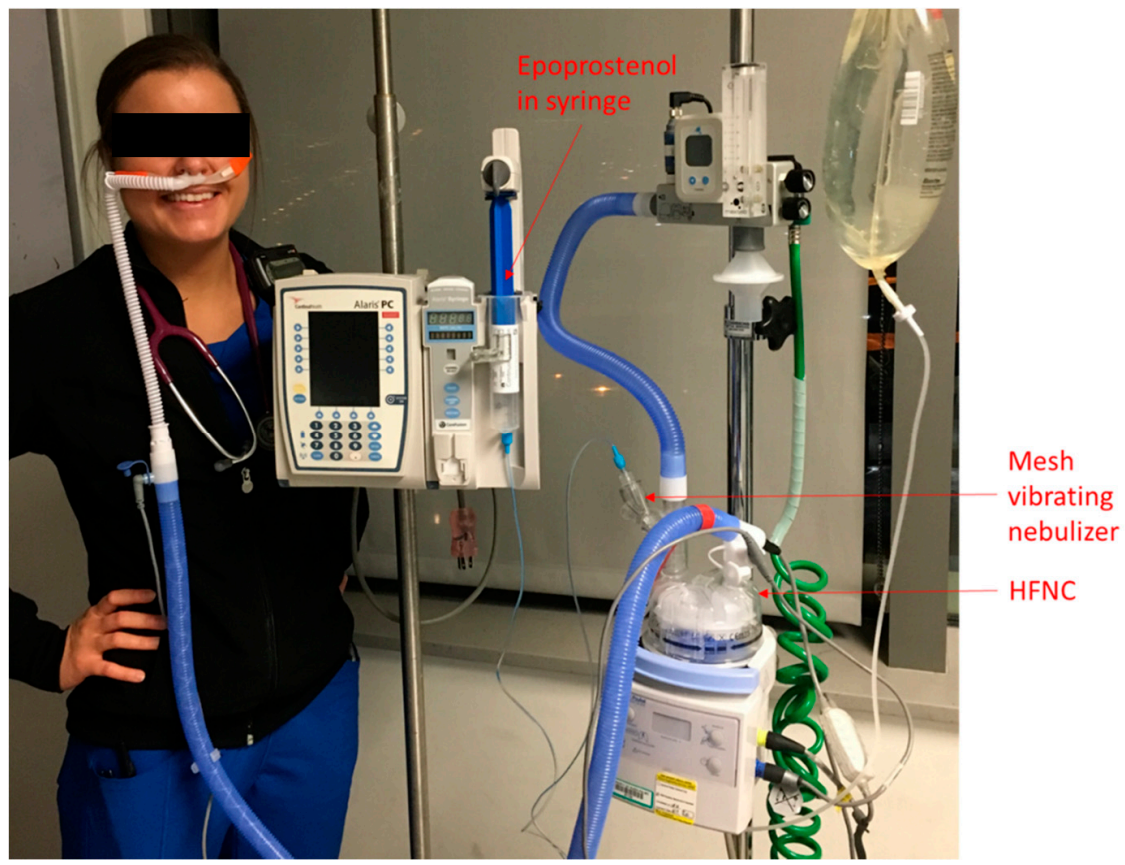

Figure 1. Set up for iEPO delivery via HFNC. iEPO, inhaled epoprostenol; HFNC, high-flow nasal cannula.

\subsection{Data Collection}

Subjects' demographic information including race, age, gender, medical history, and Acute Physiologic Assessment and Chronic Health Evaluation (APACHE II) score at ICU admission was collected. Heart rate, blood pressure, respiratory rate, $\mathrm{SpO}_{2}, \mathrm{HFNC}$ flow, and $\mathrm{F}_{\mathrm{I}} \mathrm{O}_{2}$ were collected at 30-60 min before and 30-60 min after iEPO initiation.

The primary outcome was oxygenation improvement. Because of the retrospective nature, arterial blood gases were not always available before and after initiation of $\mathrm{iEPO}$, so $\mathrm{SpO}_{2} / \mathrm{F}_{\mathrm{I}} \mathrm{O}_{2}$ was substituted for $\mathrm{PaO}_{2} / \mathrm{F}_{\mathrm{I}} \mathrm{O}_{2}$ to evaluate subjects' oxygenation [21-23]. A subject was considered a responder to iEPO if their $\mathrm{SpO}_{2} / \mathrm{F}_{\mathrm{I}} \mathrm{O}_{2}$ increased by $20 \%$ or more. Secondary outcomes were the incidence of intubation, complications including systemic hypotension, ICU stay, HFNC duration, duration of iEPO, and ICU survival.

Vasopressors (included the type and dose) and extracorporeal membrane oxygenation (ECMO) (if applicable) settings 30-60 min pre and post iEPO were also reviewed. If any change of the type and dose on the vasopressors or ECMO setting was made, the change would be collected.

\subsection{Statistical Analysis}

The Kolmogorov-Smirnov statistic tests were used to test the normality of distribution for considered variables. Continuous variables (pre and post iEPO) were expressed as mean (standard deviation [SD]) or median (Inter-Quartile Range [IQR]) and compared with Wilcoxon sign rank test, whereas differences in categorical variables were assessed with the chi-square test. A $p$-value of $<0.05$ was considered to be statistically significant for all tests. Data analysis was conducted with SPSS statistical software (SPSS 23.0 for windows; SPSS; Chicago, IL, USA). 


\section{Results}

\subsection{Demographic Information}

Between July 2015 and April 2018, 21 subjects received iEPO via HFNC, 10 subjects were excluded, and 11 subjects were enrolled. The reasons for exclusion were: 4 subjects were using iEPO during invasive ventilation and extubated to HFNC with iEPO for treating pulmonary hypertension, 4 subjects whose $\mathrm{PaO}_{2} / \mathrm{F}_{\mathrm{I}} \mathrm{O}_{2}>300$ used HFNC and iEPO for pulmonary hypertension; 1 subject used iEPO less than 10 min just for a pulmonary vaso-reactivity test; 1 subject was extubated to HFNC and iEPO for palliative care.

Among the 11 enrolled subjects, 4 (36.4\%) were male, with a mean $( \pm \mathrm{SD})$ age of $57.5 \pm 22.1 \mathrm{yrs}$. The APACHE II score at ICU admission was $18.5 \pm 5.7$. Five (45.5\%) subjects were Caucasian, 5 (45.5\%) were African American, and 1 (9.1\%) was Hispanic. Ten subjects had chronic heart or lung comorbidities, and 7 of them used home oxygen at 2-6 L/min (Table 1). Six subjects had pulmonary hypertension, 2 subjects had right heart failure, and 3 subjects had both pulmonary hypertension and right heart failure.

Only one subject started iEPO with HFNC simultaneously but did not respond to iEPO and HFNC (case 6 in Table 1). The other 10 subjects were placed on HFNC for $21(1,44)$ hours with flow setting at $40(30,50) \mathrm{L} / \mathrm{min}$ prior to starting iEPO. The dose of iEPO was initiated at $50 \mathrm{ng} / \mathrm{Kg} / \mathrm{min}$ in all except one subject (case 5 in Table 1), who started at $20 \mathrm{ng} / \mathrm{Kg} / \mathrm{min}$ and was on veno-venous extracorporeal membrane oxygenation (VV-ECMO). One other subject was also on VV-ECMO while iEPO and HFNC were initiated.

\subsection{Oxygenation Effects and Safety}

After inhaling epoprostenol, subjects' $\mathrm{SpO}_{2} / \mathrm{F}_{\mathrm{I}} \mathrm{O}_{2}$ improved from $107.5 \pm 26.3$ to $125.5 \pm 31.6$ within 30-60 $\min \left(p=0.026\right.$ ) (Figure 2). Five (45.5\%) subjects had a $\mathrm{SpO}_{2} / \mathrm{F}_{\mathrm{I}} \mathrm{O}_{2}$ improvement greater than $20 \%$. Two of these subjects' $\mathrm{SpO}_{2}$ increased from $69 \%$ (case 8) and 80\% (case 3) on $\mathrm{F}_{\mathrm{I}} \mathrm{O}_{2} 1.0$ to $93 \%$ on $\mathrm{F}_{\mathrm{I}} \mathrm{O}_{2} 0.7$ and $98 \%$ on $\mathrm{F}_{\mathrm{I}} \mathrm{O}_{2} 1.0$, respectively. When comparing these five responders with the six non-responders, responders' $\mathrm{SpO}_{2}$ improved from $(87.6 \% \pm 12.7 \%)$ to $(96.6 \% \pm 2.1 \%)$, which was significantly higher than post-iEPO $\mathrm{SpO}_{2}$ among non-responders $(p=0.03)$ (Table 2). There was no difference of comorbid pulmonary hypertension or right heart failure, HFNC flow while iEPO was being delivered, intubation, hospital survival, ICU, and hospital stay between responders and non-responders.

Heart rate, blood pressure, and respiratory rate of pre and post iEPO were not significantly different (Table 3). None of the vasopressors or ECMO settings was changed within 30-60 min of iEPO initiation. None of the subjects had to discontinue iEPO and HFNC due to discomfort or intolerance.

\subsection{Outcome}

Seven subjects including both responders and non-responders to iEPO did not require intubation, and ultimately 7 subjects were discharged from the hospital with $12(9,22.5)$ days of ICU stay. Two subjects were previously on VV-ECMO when iEPO via HFNC was initiated, and 1 withdrew therapy. 
Table 1. Individual subject's demographic characteristics, response to iEPO and outcome.

\begin{tabular}{|c|c|c|c|c|c|c|c|c|c|c|c|c|c|c|c|c|c|}
\hline ID & Gender & Race* & Age & APACHE II & Diagnosis \# & $\begin{array}{c}\text { Home } \\
\mathrm{O}_{2}\end{array}$ & $\begin{array}{l}\text { HFNC } \\
\text { Hours Pre- } \\
\text { iEPO }\end{array}$ & $\begin{array}{l}\text { Pre- } \\
\text { iEPO } \\
\mathrm{SpO}_{2}\end{array}$ & $\begin{array}{l}\text { Pre- } \\
\mathrm{iEPO} \\
\mathrm{FiO}_{2}\end{array}$ & $\begin{array}{l}\text { Pre- } \\
\text { iEPO } \\
\text { Flow }\end{array}$ & $\begin{array}{l}\text { Post- } \\
\text { iEPO } \\
\mathrm{SpO}_{2}\end{array}$ & $\begin{array}{l}\text { Post- } \\
\text { iEPO } \\
\mathrm{FiO}_{2}\end{array}$ & $\begin{array}{l}\text { Post- } \\
\text { iEPO } \\
\text { Flow }\end{array}$ & $\begin{array}{l}\text { iEPO } \\
\text { Duration } \\
\text { (Mins) }\end{array}$ & Respond \& & Intubation & Outcome \\
\hline 1 & M & 2 & 85 & 26 & $\begin{array}{l}\text { HTN, HFpEF, PH, COPD, CVA, } \\
\text { PVD, CKD, BPH s/p TURP }\end{array}$ & Yes & 11.5 & 92 & 6 & 40 & 94 & 6 & 40 & 176 & No & No & $\begin{array}{l}\text { Died in } \\
\text { hospice }\end{array}$ \\
\hline 2 & $\mathrm{~F}$ & 1 & 69 & 18 & $\begin{array}{l}\text { DLBCL s/p chemo, acute } \\
\text { respiratory failure with hypoxia, } \\
\text { sepsis; PAH }\end{array}$ & No & 44 & 96 & 1.0 & 50 & 95 & 1.0 & 40 & 1135 & No & Yes & Alive \\
\hline 3 & $\mathrm{~F}$ & 3 & 23 & 7 & $\begin{array}{l}\text { Myocarditis due to influenza A } \\
\text { virus, PH }\end{array}$ & No & 28 & 80 & 1.0 & 50 & 98 & 1.0 & 50 & 6276 & Yes & No & Alive \\
\hline 4 & F & 1 & 72 & 22 & $\begin{array}{l}\text { HTN, breast cancer, and IIIA } \\
\text { non-small cell lung cancer s/p } \\
\text { lobectomy; septic shock; RHF }\end{array}$ & No & 82 & 98 & 1.0 & 45 & 98 & 8 & 45 & 13662 & Yes & Yes & $\begin{array}{c}\text { Alive. } \\
\text { VV-ECMO } \\
\text { with iEPO }\end{array}$ \\
\hline 5 & M & 1 & 51 & 27 & $\begin{array}{l}\text { CAD, COPD, stage III squamous } \\
\text { cell carcinoma of lung; RHF } \\
\text { from PE }\end{array}$ & No & 21 & 90 & 9 & 40 & 91 & 9 & 40 & 1400 & No & No & $\begin{array}{c}\text { Died. } \\
\text { VV-ECMO } \\
\text { with iEPO, }\end{array}$ \\
\hline 6 & F & 2 & 42 & 14 & $\begin{array}{l}\text { SLE, HTN, CHF, CAD, CKD, } \\
\text { ILD, PH }\end{array}$ & Yes & 0 & 90 & 6 & 1 & 92 & 6 & 30 & 1298 & No & No & Alive \\
\hline 7 & $\mathrm{~F}$ & 1 & 61 & 16 & $\begin{array}{l}\text { group } 1 \text { PAH with connective } \\
\text { tissue disease }\end{array}$ & Yes & 1 & 91 & 8 & 35 & 94 & 1.0 & 35 & 4104 & No & No & Alive. \\
\hline 8 & F & 2 & 23 & 14 & $\begin{array}{c}\text { ASD; biventricular systolic } \\
\text { dysfunction; } \mathrm{PH} \text { (WHO group } 1 \\
\text { 2/2 ASD with Eisenmenger's), } \\
\text { chronic hypoxemia }\end{array}$ & Yes & 30.5 & 69 & 1.0 & 20 & 93 & 7 & 20 & 2089 & Yes & No & Alive \\
\hline 9 & M & 1 & 78 & 19 & $\begin{array}{l}\text { CHF, PAH (group } 1 \text { functional } \\
\text { class 3), ASD. }\end{array}$ & Yes & 2 & 93 & 1.0 & 50 & 97 & 8 & 45 & 3184 & Yes & No & Alive \\
\hline 10 & $\mathrm{M}$ & 2 & 71 & 21 & $\begin{array}{l}\mathrm{PH} \text { (moderate R to L shunt), } \\
\mathrm{HFrEF}(\mathrm{EF} 35-40 \%) \mathrm{c} / \mathrm{b} \text { VF s/p } \\
\mathrm{ICD}, \text { hypertension, CKD stage } \\
\text { IV, DM c/b retinopathy, } \\
\text { glaucoma, HLD }\end{array}$ & Yes & 1 & 98 & 8 & 30 & 97 & 5 & 30 & 944 & Yes & Yes & $\begin{array}{c}\text { Died, } \\
\text { withdrew } \\
\text { therapy }\end{array}$ \\
\hline 11 & F & 2 & 63 & 19 & $\begin{array}{c}\text { PH (chronic), chronic } \\
\text { hypoxemic respiratory failure, } \\
\text { atypical carcinoid lung tumor, } \\
\text { DM II, CKD, CAD, asthma }\end{array}$ & Yes & 54 & 85 & 8 & 30 & 89 & 8 & 30 & 9921 & No & Yes & Died \\
\hline
\end{tabular}

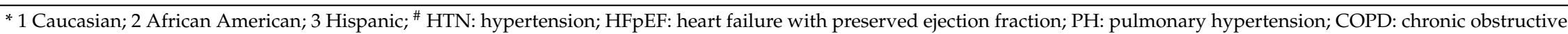
pulmonary disease; CVA: cerebrovascular accident; PVD: peripheral vascular disease; BPH s/p TURP: benign prostatic hyperplasia status post transurethral resection of the prostate; DLBCL: diffuse large B-cell lymphoma; PAH: pulmonary arteria hypertension; RHF: right heart failure; CAD: coronary artery disease; PE: pulmonary embolism; SLE: systemic lupus erythematosus; CHF: congestive heart failure; CKD: chronic kidney disease; ILD: interstitial lung disease; ASD: atrial septal defect; HFrEF: heart failure with reduced ejection fraction; VF: ventricular fibrillation; ICD: implantable cardioverter defibrillator; DM: diabetes mellitus; HLD: hypersensitivity lung disease; \& A subject was considered a responder to iEPO if their $\mathrm{SpO}_{2} / \mathrm{FIO}_{2}$ increased by $>20 \%$. 


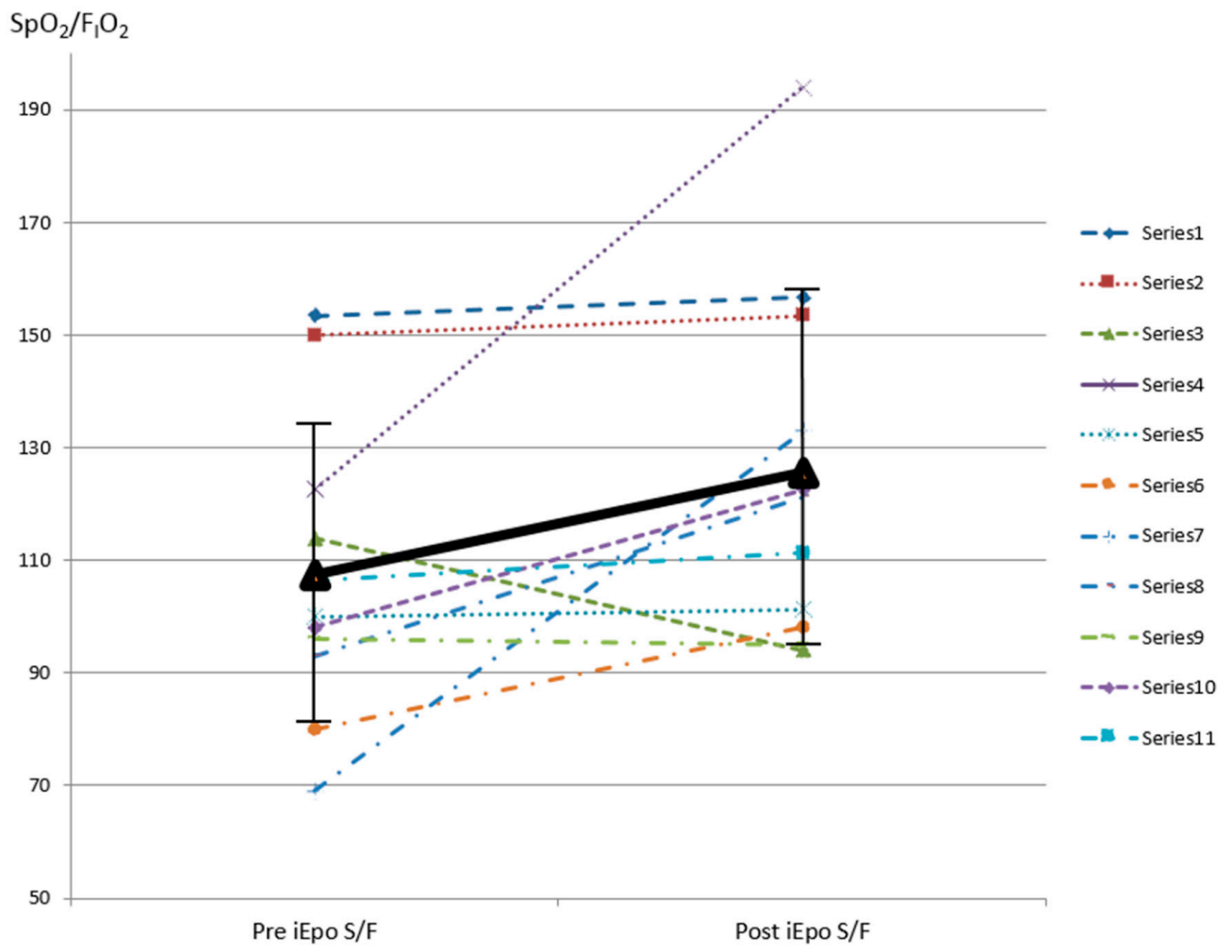

Figure 2. $\mathrm{SpO}_{2} / \mathrm{F}_{\mathrm{I}} \mathrm{O}_{2}$ pre and post $\mathrm{iEPO}$ via $\mathrm{HFNC}$ was initiated. $\mathrm{SpO}_{2}$ pulse oximetry saturation; $\mathrm{F}_{\mathrm{I}} \mathrm{O}_{2}$ fraction of inspired oxygen; iEPO inhaled epoprostenol; HFNC high-flow nasal cannula.

Table 2. Comparison between responders and non-responders.

\begin{tabular}{|c|c|c|c|}
\hline Items & Responders & Non-Responders & $p$ \\
\hline Number of subjects & 5 & 6 & \\
\hline Pulmonary hypertension & 4 & 5 & / \\
\hline Right heart failure & 3 & 2 & 0.567 \\
\hline Pre respiratory rate & $25.8 \pm 9.4$ & $25.8 \pm 7.8$ & 0.931 \\
\hline Pre $\mathrm{F}_{\mathrm{I}} \mathrm{O}_{2}$ & $96 \pm 8.9$ & $78.3 \pm 16.0$ & 0.082 \\
\hline Pre flow & $39 \pm 13.4$ & $35.8 \pm 4.9$ & 0.456 \\
\hline Pre $\mathrm{SpO}_{2}$ & $87.6 \pm 12.7$ & $90.7 \pm 3.6$ & 0.792 \\
\hline Pre $\mathrm{SpO}_{2} / \mathrm{F}_{\mathrm{I}} \mathrm{O}_{2}$ & $92.5 \pm 20.2$ & $120 \pm 25.3$ & 0.082 \\
\hline Post respiratory rate & $26.4 \pm 4.9$ & $26.3 \pm 8.8$ & 0.931 \\
\hline Post $\mathrm{F}_{\mathrm{I}} \mathrm{O}_{2}$ & $76 \pm 18.2$ & $81.7 \pm 18.3$ & 0.662 \\
\hline Post flow & $38 \pm 12.6$ & $35.8 \pm 4.9$ & 0.537 \\
\hline Post $\mathrm{SpO}_{2}$ & $96.6 \pm 2.1$ & $92.5 \pm 2.3$ & 0.03 \\
\hline Post $\mathrm{SpO}_{2} / \mathrm{F}_{\mathrm{I}} \mathrm{O}_{2}$ & $133.7 \pm 36$ & $118.6 \pm 28.9$ & 0.429 \\
\hline Intubation & 2 & 3 & / \\
\hline ICU stay & $12(7,24)$ & $14(10,21)$ & 0.931 \\
\hline Hospital stay & $12(7,24)$ & $16(11,21)$ & 0.792 \\
\hline Hospital survival & 4 & 3 & / \\
\hline
\end{tabular}

Table 3. Comparison between pre and post iEPO.

\begin{tabular}{cccc}
\hline Items & Pre iEpo & Post iEpo & $p$ \\
\hline $\mathrm{HR}$ (beats/min) & $108.1 \pm 31.1$ & $101.1 \pm 20.4$ & 0.284 \\
$\mathrm{mBP}(\mathrm{mmHg})$ & $87.7 \pm 15.8$ & $89.4 \pm 16.2$ & 0.824 \\
$\mathrm{RR}($ breaths $/ \mathrm{min})$ & $25.8 \pm 8.1$ & $26.4 \pm 7.0$ & 0.681 \\
$\mathrm{SpO}_{2} / \mathrm{F}_{\mathrm{I}} \mathrm{O}_{2}$ & $107.5 \pm 26.3$ & $125.5 \pm 31.6$ & 0.026 \\
$\mathrm{~F}_{\mathrm{I}} \mathrm{O}_{2}$ & $0.9(0.8,1.0)$ & $0.8(0.65,0.95)$ & 0.129 \\
$\mathrm{SpO}_{2}(\%)$ & $91.5(90,96)$ & $94.4 \pm 3.0$ & 0.016 \\
Flow $(\mathrm{L} / \mathrm{min})$ & $40(30,50)$ & $40(30,45)$ & 0.066 \\
\hline
\end{tabular}




\section{Discussion}

In our study, we found that subjects' oxygenation was improved after iEPO was initiated via HFNC, which was consistent with the iEPO effects on the mechanically ventilated patients [5-7] and spontaneous breathing patients with HFNC in Ammar et al.'s study [24]. However, Ammar et al. did not differentiate the effects of HFNC and iEPO on oxygenation improvement. HFNC has been shown to improve oxygenation, thus it is difficult to isolate the benefits of iEPO from HFNC [25]. In our study, only 1 subject started iEPO and HFNC simultaneously, but did not respond. The other 10 subjects had utilized HFNC for $\geq 1 \mathrm{~h}$, which was a sufficient time interval for $\mathrm{SpO}_{2}$ to have stabilized from the increase in delivered $\mathrm{F}_{\mathrm{I}} \mathrm{O}_{2}$ attributed to HFNC. Additionally, the HFNC flow setting was maintained or reduced after initiating iEPO in all patients, which should not have resulted in further improvement in oxygenation in the relative short period of time between the pre and post assessment of iEPO (30-60 min). Thus, the improvement of oxygenation most likely was due to the initiation of iEPO. Moreover, no complication, such as systemic hypotension, was observed in the subjects after the initiation of iEPO via HFNC. With this novel route, intubation may have been avoided in a majority of the subjects. In two of these subjects (cases 3 and 8), iEPO was utilized as the last resort before intubation.

It should also be acknowledged that not all of the hypoxemia subjects responded to iEPO. Identifying responders to iEPO might help discern patients likely to benefit from this combination therapy and avoid delaying other interventions such as intubation [26]. In Kallet et al.'s study on mechanical ventilation, 208 ARDS subjects were included, and only $62 \%$ responded to iEPO. The response rate decreased if the primary source of ARDS was lung related [27]. This finding might explain the low response rate (45\%) in our study as all of the subjects had pulmonary etiology. The other explanation might come from subjects' baseline oxygenation. Kallet et al. found that the baseline oxygenation was significantly related to ARDS patients' response to iEPO while patients with lower baseline oxygenation had less response to iEPO [27]. In our study, all the subjects' baseline $\mathrm{SpO}_{2} / \mathrm{F}_{\mathrm{I}} \mathrm{O}_{2}$ was $\leq 150$, which was in the lowest group in Kallet et al.'s study. As a practical substitute to $\mathrm{PaO}_{2} / \mathrm{F}_{\mathrm{I}} \mathrm{O}_{2}$, $\mathrm{SpO}_{2} / \mathrm{F}_{\mathrm{I}} \mathrm{O}_{2}$ has been shown to have a strong linear relationship in moderate to severe ARDS [22,23] and was recommended as a diagnostic tool for early enrollment in clinical trial [23].

Flow has been reported to be a critical factor in the lung deposition of aerosol delivery via HFNC [11-14]. If flow was increased from 30 to $50 \mathrm{~L} / \mathrm{min}$ in quiet breathing subjects, the lung deposition was found to decrease from $(11.6 \pm 1.2) \%$ to $(3.5 \pm 0.2) \%$ in a bench study [12] and from $(3.76 \pm 1.36) \%$ to $(2.23 \pm 0.81) \%$ in a scintigraphy study [14]. However, Réminiac et al. [11] and Dailey et al. [12] found that distressed breathing significantly increased lung deposition. Our previous adult and pediatric in vitro studies found that inhaled dose was higher with gas flow below subjects' inspiratory flow than that with gas flow exceeding subjects' inspiratory flow $[13,28]$, with optimal gas flow rate at $50 \%$ patient's inspiratory flow [28]. Subjects in our study had tachypnea, so the optimal flow for them may be higher in order to generate better aerosol deposition than the gas flow for the healthy volunteers in the scintigraphy study. Subjects receiving a higher lung dose may have been responders to iEPO since response is dose related [5]. More prospective studies are needed to further explore the relationship between lung dose and flow on subjects' response in hypoxemic patients as well as to explore the effective dose of iEPO via HFNC.

Besides the benefits from high flow in aerosol delivery to hypoxemic patients, the positive expiratory pressure (PEP) also influences the lung deposition of aerosol delivery, which might be due to the increment of end-expiratory lung volumes. Alcoforado et al. found that the combination of a PEP device and jet nebulizer had significantly higher lung deposition than the jet nebulizer alone [29]. HFNC generates $2-4 \mathrm{cmH}_{2} \mathrm{O}$ positive expiratory pressure for adults on higher flow rate during HFNC when the subject's mouth is closed [30]. Therefore, higher flow not only meets hypoxemia patients' inspiratory flow demand, but may optimize aerosol delivery. This combination of HFNC with a high flow rate and iEPO may be beneficial for adult subjects who have severe hypoxemia with pulmonary hypertension or right heart dysfunction. 
Pacheco et al. found that ARDS patients' response to iEPO was identified as an independent predictor of 90-day mortality [31]. Kallet et al. also found that patients who responded to iEPO had an improved hospital and 90-day outcome [26]. These findings imply that closely monitoring patients' response to iEPO may provide important feedback regarding their prognosis. Due to our small sample size, the mortality difference observed between groups cannot be extrapolated to demonstrate an overall benefit. Future studies on ARDS patients' response to iEPO via HFNC with larger sample size are necessary to explore these findings.

A major limitation of this study was its retrospective nature. Due to this, we were unable to evaluate subjects' pulmonary vasculature resistance or heart function as only two subjects had a pulmonary artery catheter placed, and neither of them had the parameters measured 30-60 min before and after iEPO was initiated. ICU patients' situation changed fast, thus immediate assessment might better reflect the direct response from iEPO. However, acquiring ABG 30-60 min before and after initiating iEPO for all patients was not realistic, thus $\mathrm{SpO}_{2} / \mathrm{F}_{\mathrm{I}} \mathrm{O}_{2}$ had to be substituted for $\mathrm{PaO}_{2} / \mathrm{F}_{\mathrm{I}} \mathrm{O}_{2}$ as a means for evaluating oxygenation [21-23]. Additionally, if the HFNC flow was set lower than subjects' inspiratory flow, the actual $\mathrm{F}_{\mathrm{I}} \mathrm{O}_{2}$ subjects inhaled was lower than the setting values due to the air entrainment. However, HFNC flows for all the subjects in our study were maintained or reduced after iEPO was initiated, thus using $\mathrm{SpO}_{2} / \mathrm{F}_{\mathrm{I}} \mathrm{O}_{2}$ to evaluate subjects' response was stricter, as the actual $\mathrm{F}_{\mathrm{I}} \mathrm{O}_{2}$ post-iEPO might be lower than the setting value which was utilized to calculate. A second limitation was the small sample size. This could explain why the difference in responders and non-responders was not significant, except for $\mathrm{SpO}_{2} / \mathrm{F}_{\mathrm{I}} \mathrm{O}_{2}$. A larger sample size in a prospective pre-post study is needed. Thirdly, we did not have the control group to compare the difference of HFNC with or without iEPO, especially the long-term benefits and outcomes. The results from this study need to be interpreted cautiously, and a randomized control trial is needed.

\section{Conclusion}

This retrospective study demonstrated the feasibility of inhaled epoprostenol via HFNC in improving oxygenation in adult subjects with severe hypoxemia with pulmonary hypertension or right heart dysfunction. Carefully titrating flow and cautiously evaluating clinical response may help identify responders and avoid delaying other interventions. Overall, this study supports the need for larger prospective randomized control trials to further evaluate the efficacy of iEPO via HFNC.

Author Contributions: Conceptualization, J.Li., K.M.R, and D.V; methodology, J.Li and K.M.R; validation, J.Li and L.J.H; formal analysis, J.Li; investigation, L.J.H., B.M., S.A.H., and J.Liu; resources, J.Li, K.M.R and D.V.; data curation, J.Li, L.J.H, B.M., S.A.H., and J. Liu.; writing-original draft preparation, J.Li; writing-review and editing, J.Li, L.J.H., S.A.H., B.M., K.M.R., J.Liu., S.M., and D.V.; supervision, K.M.R., S.M., and D.V.; project administration, J.Li., K.R.M, and D.V.

Funding: This research received no external funding.

Acknowledgments: We thank the adult section respiratory therapists in respiratory care department at Rush University Medical Center for helping to implement the inhaled epoprostenol project.

Conflicts of Interest: The authors declare no conflict of interest.

\section{References}

1. Elmi-Sarab, M.; Deschamps, A.; Delisle, S.; Ased, H.; Haddad, F.; Lamarche, Y.; Perrault, L.P.; Lambert, J.; Turgeon, A.F.; Denault, A.Y. Aerosolized vasodilators for the treatment of pulmonary hypertension in cardiac surgical patients: A systematic review and meta-analysis. Anesth. Analg. 2017, 125, 393-402. [CrossRef] [PubMed]

2. Abe, S.; Ishida, K.; Masuda, M.; Ueda, H.; Kohno, H.; Matsuura, K.; Tamura, Y.; Watanabe, M.; Matsumiya, G. A prospective; randomized study of inhaled prostacyclin versus nitric oxide in patients with residual pulmonary hypertension after pulmonary endarterectomy. Gen. Thorac. Cardiovasc. Surg. 2017, 65, 153-159. [CrossRef] [PubMed] 
3. McGinn, K.; Reichert, M.A. Comparison of inhaled nitric oxide versus inhaled epoprostenol for acute pulmonary hypertension following cardiac surgery. Ann. Pharmacother. 2016, 50, 22-26. [CrossRef] [PubMed]

4. Preston, I.R.; Sagliani, K.D.; Roberts, K.E.; Shah, A.M.; DeSouza, S.A.; Howard, W.; Brennan, J.; Hill, N.S. Comparison of acute hemodynamic effects of inhaled nitric oxide and inhaled epoprostenol in patients with pulmonary hypertension. Pulm. Circ. 2013, 3, 68-73. [CrossRef] [PubMed]

5. Fuller, B.M.; Mohr, N.M.; Skrupky, L.; Shah, A.M.; Desouza, S.A.; Howard, W.; Brennan, J.; Hill, N.S. The use of inhaled prostaglandins in patients with ARDS: A systematic review and meta-analysis. Chest 2015, 147, 1510-1522. [CrossRef] [PubMed]

6. Ammar, M.A.; Bauer, S.R.; Bass, S.N.; Sasidhar, M.; Mullin, R.; Lam, S.W. Noninferiority of Inhaled Epoprostenol to Inhaled Nitric Oxide for the Treatment of ARDS. Ann. Pharmacother. 2015, 49, 1105-1112. [CrossRef] [PubMed]

7. Torbic, H.; Szumita, P.M.; Anger, K.E.; Nuccio, P.; LaGambina, S.; Weinhouse, G. Inhaled epoprostenol vs inhaled nitric oxide for refractory hypoxemia in critically ill patients. J. Crit. Care 2013, 28, 844-848. [CrossRef] [PubMed]

8. Zhu, Y.; Yin, H.; Zhang, R.; Wei, J. High-flow nasal cannula oxygen therapy versus conventional oxygen therapy in patients with acute respiratory failure: A systematic review and meta-analysis of randomized controlled trials. BMC Pulm. Med. 2017, 17, 201. [CrossRef] [PubMed]

9. Ni, Y.-N.; Luo, J.; Yu, H.; Liu, D.; Liang, B.-M.; Yao, R.; Liang, Z.-A. Can high-flow nasal cannula reduce the rate of reintubation in adult patients after extubation? A meta-analysis. BMC Pulm. Med. 2017, 17, 142. [CrossRef]

10. Ari, A. Aerosol drug delivery through high flow nasal cannula. Curr. Pharm. Biotechnol. 2017, 18, 877-882. [CrossRef]

11. Réminiac, F.; Vecellio, L.; Heuze-Vourc, N.; Petitcollin, A.; Respaud, R.; Cabrera, M.; Le Pennec, D.; Diot, P.; Ehrmann, S. Aerosol Therapy in Adults Receiving High Flow Nasal Cannula Oxygen Therapy. J. Aerosol Med. Pulm. Drug Deliv. 2016, 29, 134-141. [CrossRef] [PubMed]

12. Dailey, P.; Harwood, R.; Walsh, K.; Fink, J.B.; Thayer, T.; Gagnon, G.; Ari, A. Aerosol Delivery Through Adult High Flow Nasal Cannula with Heliox and Oxygen. Respir. Care 2017, 62, 1186-1192. [CrossRef] [PubMed]

13. Li, J.; Gong, L.; Ari, A.; Fink, J.B. Decrease the flow setting to improve trans-nasal pulmonary aerosol delivery via "high-flow nasal cannula" to infants and toddlers. Pediatr. Pulmonol. 2019, 54, 914-921. [CrossRef] [PubMed]

14. Alcoforado, L.; Ari, A.; Barcelar, J.M.; Brandão, C.S.S.; Fink, J.B.; Dornelas de Andrade, A. Deposition of aerosol via high flow nasal cannula is impacted by gas flow and heated humidity in vivo and in vitro. Am. J. Respir. Crit. Care Med. 2017, 195, A3683.

15. Dugernier, J.; Hesse, M.; Jumetz, T.; Bialais, E.; Roeseler, J.; Depoortere, V.; Michotte, J.B.; Wittebole, X.; Ehrmann, S.; Laterre, P.F.; et al. Aerosol delivery with two nebulizers through high-flow nasal cannula: A randomized cross-over single-photon emission computed tomography-computed tomography study. J. Aerosol. Med. Pulm. Drug Deliv. 2017, 30, 349-358. [CrossRef] [PubMed]

16. Morgan, S.E.; Mosakowski, S.; Solano, P.; Hall, J.B.; Tung, A. High-flow nasal cannula and aerosolized $\beta$ agonists for rescue therapy in children with bronchiolitis: A case series. Respir. Care 2015, 60, e161. [CrossRef] [PubMed]

17. Baudin, F.; Buisson, A.; Vanel, B.; Massenavette, B.; Pouyau, R.; Javouhey, E. Nasal high flow in management of children with status asthmaticus: a retrospective observational study. Ann. Intensive Care 2017, 7, 55. [CrossRef]

18. Bräunlich, J.; Wirtz, H. Oral versus nasal high-flow bronchodilator inhalation in chronic obstructive pulmonary disease. J. Aerosol. Med. Pulm. Drug Deliv. 2018, 31, 248-254. [CrossRef]

19. Reminiac, F.; Vecellio, L.; Bodet-Contentin, L.; Gissot, V.; Le Pennec, D.; Gandonnière, C.S.; Cabrera, M.; Dequin, P.-F.; Plantier, L.; Ehrmann, S. Nasal high-flow bronchodilator nebulization: A randomized cross-over study. Ann. Intensive Care 2018, 8, 128. [CrossRef]

20. Madney, Y.M.; Fathy, M.; Elberry, A.A.; Rabea, H.; Abdelrahim, M.E. Aerosol delivery through an adult high-flow nasal cannula circuit using low-flow oxygen. Respir. Care 2019, 64, 453-461. [CrossRef] 
21. Rice, T.W.; Wheeler, A.P.; Bernard, G.R.; Hayden, D.L.; Schoenfeld, D.A.; Ware, L.B. National Institutes of Health, National Heart, Lung, and Blood Institute ARDS Network. Comparison of the $\mathrm{SpO}_{2} / \mathrm{FIO}_{2}$ ratio and the $\mathrm{PaO}_{2} / \mathrm{FIO}_{2}$ ratio in patients with acute lung injury or ARDS. Chest 2007, 132, 410-417. [CrossRef] [PubMed]

22. Chen, W.; Janz, D.R.; Shaver, C.M.; Bernard, G.R.; Bastarache, J.A.; Ware, L.B. Clinical characteristics and outcomes are similar in ARDS diagnosed by oxygen saturation/ $/ \mathrm{Fio}_{2}$ ratio compared with $\mathrm{PaO}_{2} / \mathrm{Fio}_{2}$ ratio. Chest 2015, 148, 1477-1483. [CrossRef] [PubMed]

23. Pisani, L.; Roozeman, J.-P.; Simonis, F.D.; Giangregorio, A.; Van Der Hoeven, S.M.; Schouten, L.R.; Horn, J.; Neto, A.S.; Festic, E.; Dondorp, A.M.; et al. Risk stratification using $\mathrm{SpO}_{2} / \mathrm{FiO}_{2}$ and PEEP at initial ARDS diagnosis and after $24 \mathrm{~h}$ in patients with moderate or severe ARDS. Ann. Intensive Care 2017, 7, 108. [CrossRef] [PubMed]

24. Ammar, M.A.; Sasidhar, M.; Lam, S.W. Inhaled Epoprostenol Through Noninvasive Routes of Ventilator Support Systems. Ann. Pharmacother. 2018, 52, 1173-1181. [CrossRef] [PubMed]

25. Li, J.; Zhong, M. Comment: Inhaled epoprostenol through noninvasive routes of ventilator support systems. Ann. Pharmacother 2019, 53, 326. [CrossRef]

26. Attaway, A.H.; Myers, C.; Velani, S.; Schilz, R. Inhaled prostacyclin as salvage therapy for ARDS: Can we find the right patient? Respir. Care 2017, 62, 1113-1115. [CrossRef] [PubMed]

27. Kallet, R.H.; Burns, G.; Zhuo, H.; Ho, K.; Phillips, J.S.; Pangilinan, L.P.; Yip, V.; Gomez, A.; Lipnick, M.S. Severity of hypoxemia and other factors that influence the response to aerosolized prostacyclin in ARDS. Respir. Care 2017, 62, 1014-1022. [CrossRef]

28. Li, J.; Gong, L.; Fink, J.B. The ratio of nasal cannula gas flow to patient inspiratory flow on trans-nasal pulmonary aerosol delivery for adults: An in vitro study. Pharmaceutics 2019, 11, 225. [CrossRef]

29. Alcoforado, L.; Brandão, S.; Rattes, C.; Brandão, D.; Lima, V.; Ferreira Lima, G.; Fink, J.B.; Dornelas de Andrade, A. Evaluation of lung function and deposition of aerosolized bronchodilators carried by heliox associated with positive expiratory pressure in stable asthmatics: A randomized clinical trial. Respir. Med. 2013, 107, 1178-1185. [CrossRef]

30. Luo, J.C.; Lu, M.S.; Zhao, Z.H.; Jiang, W.; Xu, B.; Weng, L.; Li, T.; Du, B. Positive end-expiratory pressure effect of 3 high-flow nasal cannula devices. Respir. Care 2017, 62, 888-895. [CrossRef]

31. Pacheco, J.; Arnold, H.; Skrupky, L.; Watts, P.; Micek, S.T.; Kollef, M.H. Predictors of outcome in 216 subjects with ARDS treated with inhaled epoprostenol. Respir. Care 2014, 59, 1178-1185. [CrossRef] [PubMed] 